\title{
Rancangan Aplikasi Penentuan Dosen Berprestasi Pada Akademi Keperawatan Yatna Yuana Lebak Berbasis Web
}

\author{
Ramdani Budiman ${ }^{1}$ \\ Mohamad Hilman ${ }^{2}$ \\ Mochamad Faiz Ramdhani ${ }^{3}$ \\ ${ }^{1}$ Program Studi Teknik Informatika, Fakultas Ilmu Komputer, Universitas Banten Jaya \\ ${ }^{2}$ Program Studi Informatika,Fakultas Teknik,Universitas Sultan Agung Tirtayasa \\ ${ }^{3}$ Program Studi Sistem Informasi, Fakultas Sains dan Teknologi ,Universitas Raharja \\ E-mail: ${ }^{1}$ ramdani.budiman@unbaja.ac.id, ${ }^{2}$ mohamad.hilman@untirta.ac.id , \\ 3m.faiz@raharja.info
}

\begin{abstract}
Abstrak
Berdasarkan pedoman beban kerja dosen dan evaluasi pelaksanaan tridharma perguruan tinggi direktorat jenderal pendidikan tinggi departemen pendidikan nasional tahun 2014 tugas utama dosen adalah melaksanakan tridharma perguruan tinggi, Pelaksanaan tugas utama dosen ini perlu dievaluasi dan dilaporkan secara periodik sebagai bentuk akuntabilitas kinerja dosen kepada para pemangku kepentingan. Dalam penelitian ini bertujuan untuk merancang sebuah aplikasi berbasis webyang otentik dan objektif untuk penilaian kinerja. Proses pemilihan dosen berprestasi tidak boleh dipengaruhi unsur subjektifitas dari yang memilih, sehingga dirasakan kurang mendukung proses tersebut. Untuk mengatasi permasalahan diatas, maka dibuatkan suatu aplikasi berbasis web untuk membantu proses pemilihan dosen berprestasi di Akademi Keperawatan Yatna Yuana Lebak. Teknik pengumpulan data pada penelitian ini ada empat yaitu observasi,wawancara,studi kepustakaan,kuesioner.

Untuk perancangan sistem menggunakan model UML(Unified Model language).Dengan adanya sistem ini diharapkan bisa mengevaluasi sejauh mana sistem yang telah dilaksanakan dapat berpengaruh terhadap kualitas pendidikan di Akademi Keperawatan Yatna Yuana Lebak.
\end{abstract}

Kata kunci-Aplikasi,Dosen, Berprestasi,Web

\begin{abstract}
Based on the lecturer's workload guidelines and evaluation of the implementation of the higher education tri dharma, the directorate general of higher education at the national education department in 2014, the main task of the lecturer is to carry out the higher education tri dharma. The implementation of the lecturer's main duties needs to be evaluated and reported periodically as a form of accountability for the lecturer's performance to stakeholders. This study aims to design an authentic and objective web-based application for performance assessment. The selection process for outstanding lecturers should not be influenced by the element of subjectivity from those who choose, so it is felt that they do not support the process. To overcome the above problems, a web-based application was made to assist the process of selecting outstanding lecturers at the Yatna Yuana Lebak Nursing Academy. There were four data collection techniques in this study, namely observation, interviews, literature study, and questionnaires.For system design using the UML (Unified Model Language) model. With this system, it is hoped that it can evaluate the extent to which the system that has been implemented can affect the quality of education at the AYatna Yuana Lebak.
\end{abstract}

Keywords-Aplication, Lecture,Archiver, Web 


\section{PENDAHULUAN}

Salah satu upaya lain untuk meningkatkan kualias dosen yaitu dengan memberikan apresiasi kepada dosen yang berprestasi. Berdasarkan Undang-undang No 14 tahun 2005 tentang Guru dan Dosen, Pasal 51 Ayat (1) Butir b, bahwa dosen berhak mendapatkan promosi dan penghargaan sesuai dengan kinerja akademiknya. Dengan acuan diatas maka Akademi Keperawatan Yatna Yuana Lebak perlu mengadakan pemilihan dosen berprestasi setiap tahunya untuk menilai kinerja dosen tiap tahunnya.

Pemilihan dosen berprestasi dilakukan oleh tim penilai yang dibentuk oleh SPMI (Sistem Penjamin Mutu Internal) Akademi Keperawatan Yatna Yuana Lebak. Proses pemilihan dosen berprestasi tidak boleh dipengaruhi unsur subjektifitas dari yang memilih, sehingga dirasakan kurang mendukung proses tersebut. Apabila terjadi ketidaktepatan tim penilai dan mahasiswa dalam memberikan penilaian kepada setiap dosen karena adanya beberapa kriteria yang bersifat subjektif, maka penilain diberikan masih bersifat tidak pasti dan tidak jelas karena dimungkinkan muncul ketidaktepatan dalam memberikan nilai kepada dosen yang akan berdampak pada hasil pemilihan terhadap dosen diberikan menjadi kurang akurat dan tepat.

Untuk mengatasi permasalahan diatas, maka dibuatkan suatu aplikasi berbasis web untuk membantu proses pemilihan dosen berprestasi di Akademi Keperawatan Yatna Yuana Lebak. Pembuatan aplikasi ini diharapkan akan menyelesaikan permasalahan yang dihadapi, dan menghasilkan rekomendasi keputusan yang bisa membantu Tim Penilai untuk menentukan siapa yang benar-benar layak mendapat predikat dosen berprestasi.

\section{METODE PENELITIAN}

\subsection{Teknik Pengumpulan Data}

Teknik pengumpulan data yang digunakan dalam penelitian ini ada empat, yaitu:

1. Metode Observasi (Pengamatan)

Merupakan cara pengumpulan data dimana peneliti tidak memiliki kendali sama sekali terhadap pemunculan respon objek yang diamati, kecuali dalam menentukan faktor yang diamati dan memeriksa ketelitian data. Penelitian dilaksanakan langsung ke Akademi Keperawatan Yatna Yuana Lebak yang menjadi lokasi penelitian guna memperoleh data dan keterangan.

2. Metode Wawancara

Melakukan konsultasi maupun tanya jawab secara interaktif kepada pihak Kepegawaian Akademi Keperawatan Yatna Yuana Lebak, data yang sudah diperoleh kemudian diolah untuk rencana pengembangan aplikasiPenilaian Dosen Berprestasi pada Akademi Keperawatan Yatna Yuana Lebak yang akan dibuat.

3. Studi Kepustakaan

Studi pustaka dilakukan dengan mengumpulkan data dan informasi yang digunakan sebagai acuan dalam pembuatan aplikasi sistem pendukung keputusan. Data dan informasi dapat berupa buku-buku ilmiah, jurnal, tesis, laporan penelitian dan sumber-sumber lainnya baik cetak maupun elektronik yang berhubungan dengan pemahaman tentang penilaian kinerja dosen pada proses belajar mengajar, sistem pendukung keputusan, metode simple additive weighting.

4. Kuesioner

Kuesioner berisikan pertanyaan-pertanyaan terstruktur yang berkaitan dengan permasalahan dalam penelitian implementasi sistem Penilaian dosen.Kuesioner ini nantinya akan disebarkan kepada responden atau objek yang menjadi pusat penelitian yaitu para dosen Akademi Keperawatan Yatna Yuana Lebak tahun akademik2016-2017.

\subsection{Metode Perancangan}


Rancangan aplikasi menggunakan metode Unified Modelling Language (UML) yang akan dituangkan dalam tahap : pembuatan Use Case Diagram, Sequence Diagram, Activity Diagram, dan Class Diagram. Menurut Law (2015) di dalam bukunya menjelaskan, "Unified Modeling Language (UML) adalah bahasa yang dirancang sebagai standar untuk visualisasi sistem perangkat lunak.

\section{HASIL DAN PEMBAHASAN}

Model dari sistem yang diusulkan akan dibuat dengan unifed Modeling Language ( UML ). Diagram yang dibuat dengan Usecase Diagram dan Activity Diagram.

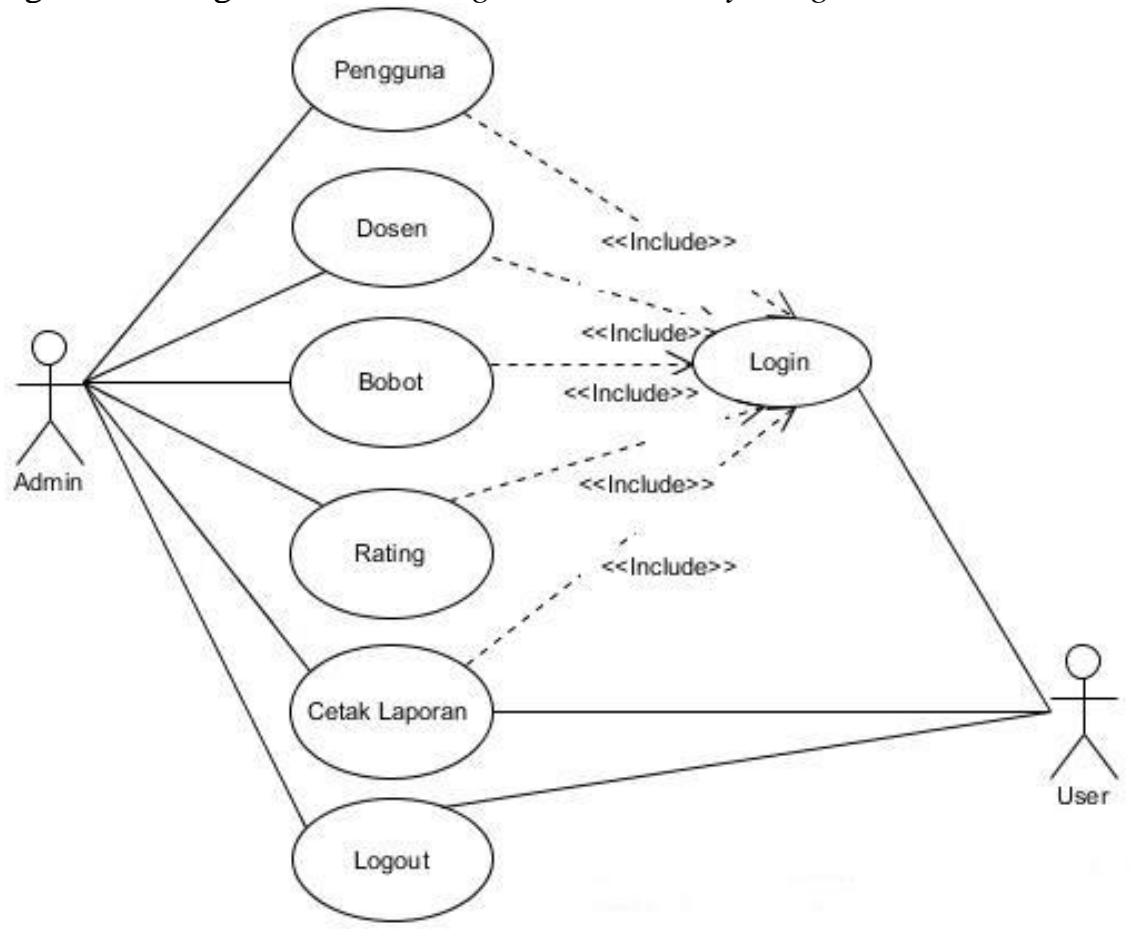

Gambar 1 Use Case Diagramlogin 


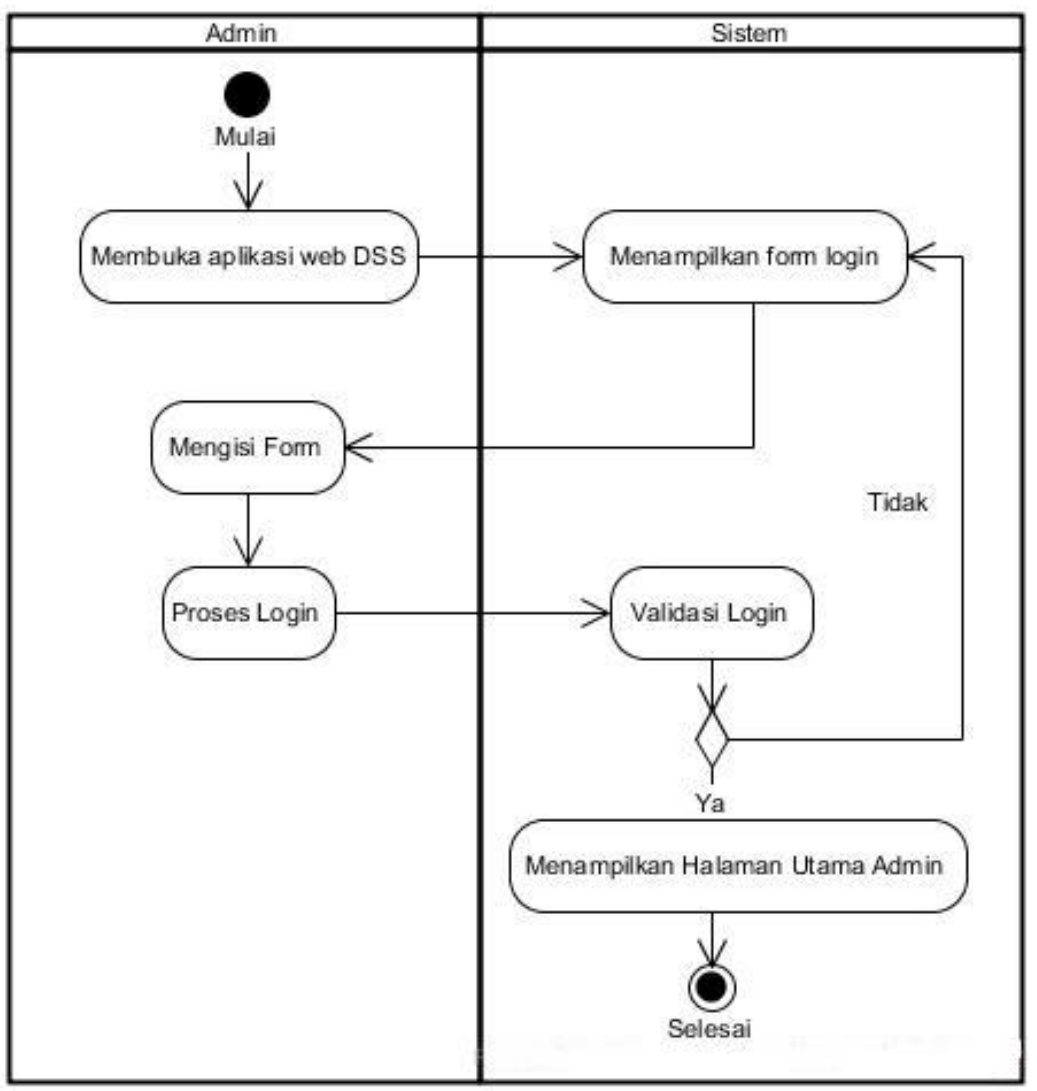

Gambar 2 Activity Diagram Login

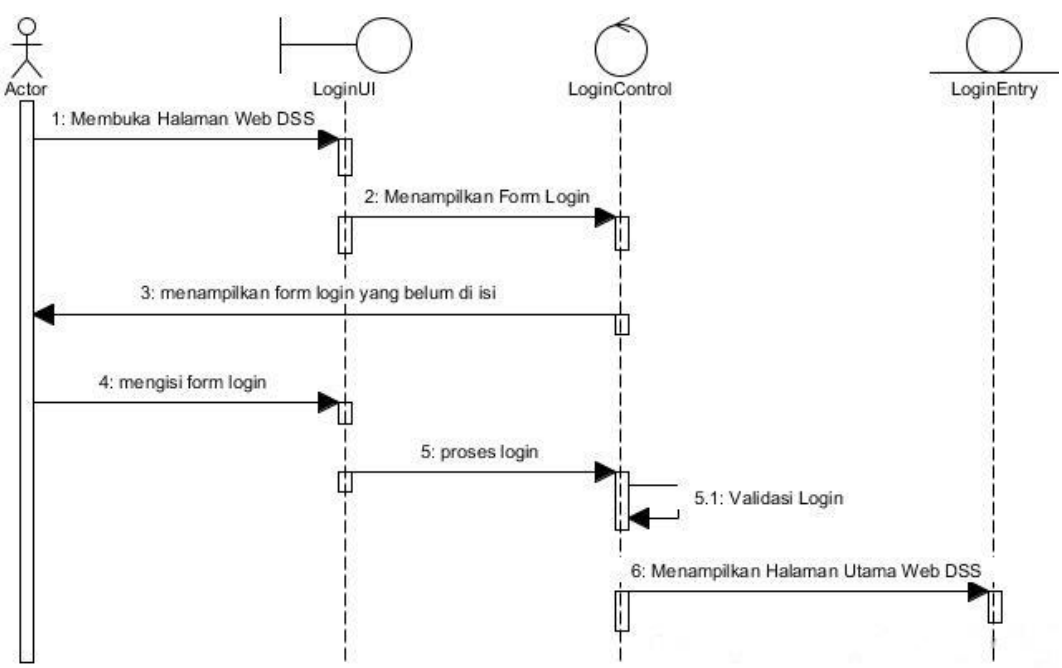

Gambar 3 Sequence Diagram Login

Tampilan awal yang akan pengguna temukan adalah menu LOGIN, yaitu sebuah menu dimana pengguna diharuskan memasukan nama dan kata kunci yang telah diinformasikan sebelumnya, hanya pengguna yang diberi hak mengakses sistem yang dapat masuk ke dalam sistem, sebagaimana gambar 4 berikut ini : 
ISSN: 2461-1409

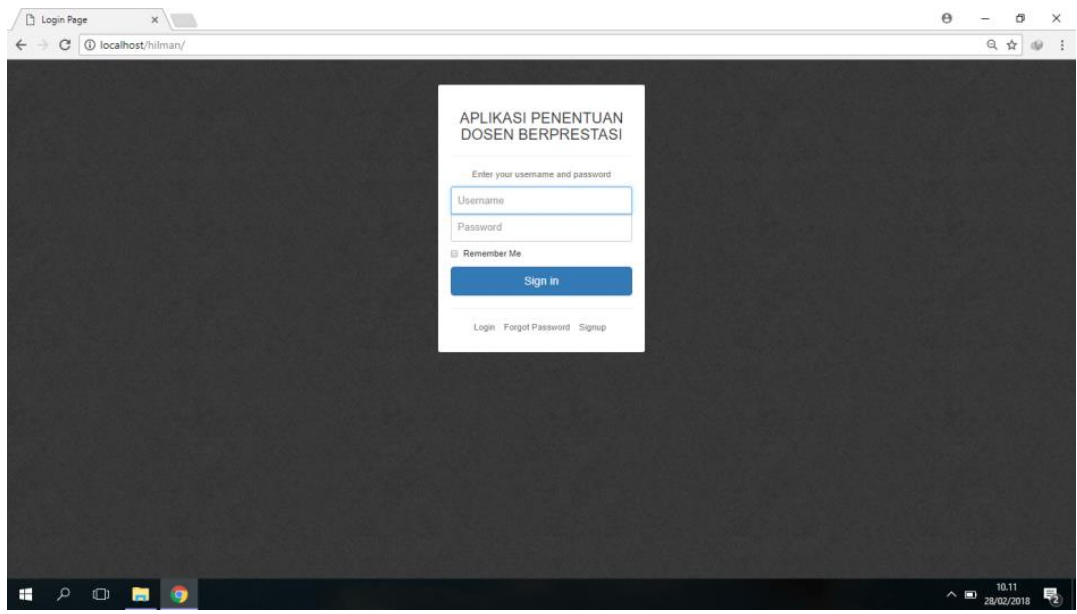

Gambar 4 Menu Login

Apabila seorang pengguna diberi akses untuk memasuki sistem, maka pengguna akan dapat melihat tampilan utama sistem sebagaimana gambar 5 berikut ini :

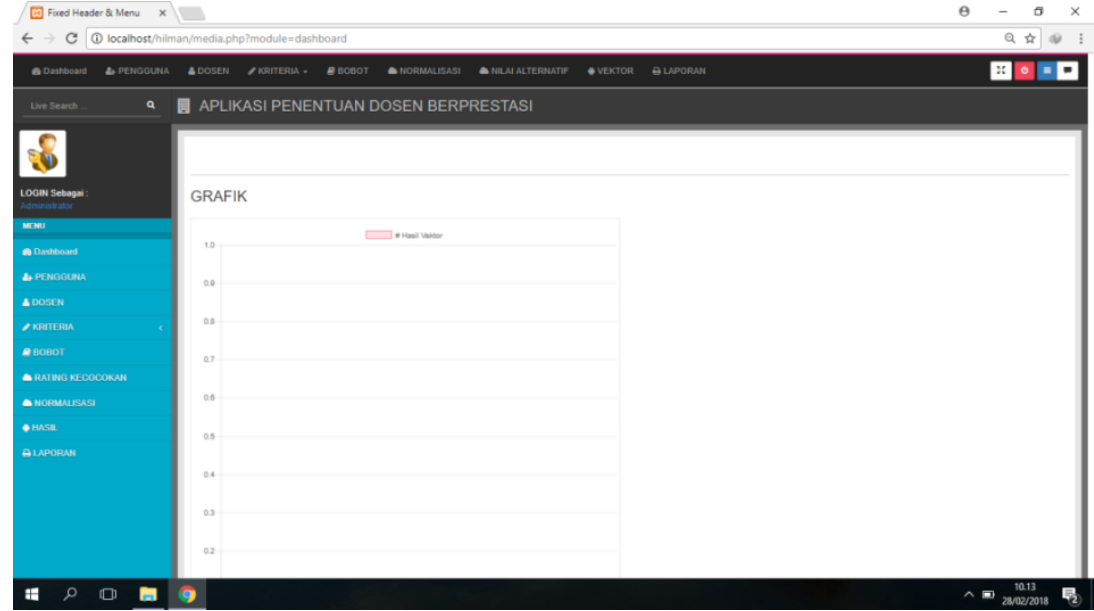

Gambar 5 Tampilan Menu Utama

Tampilan menu dosen terdiri dari tombol tambah untuk menambahkan daftar dosen beserta tombol edit untuk mengedit data dosen dan tombol hapus untuk menghapus data dosen, berikut ini gambar 6 menu dosen : 


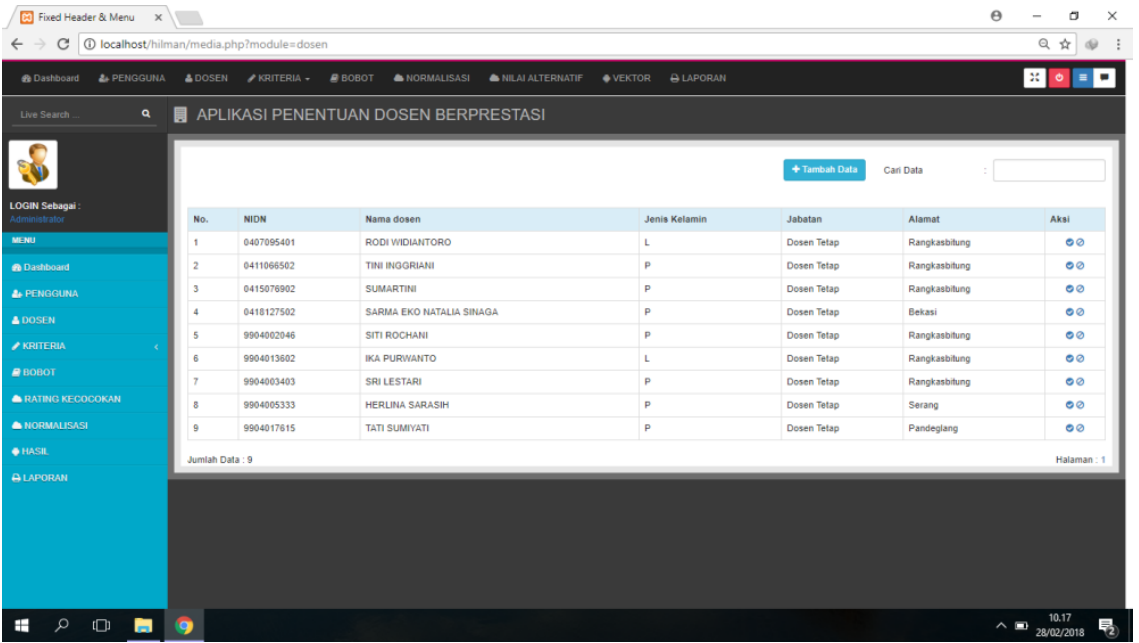

Gambar 6 Tampilan menu dosen

Tampilan menu kriteria berisikan display 12 kriteria yang telah ditentukan, berikut ini gambar 7 menu kriteria :

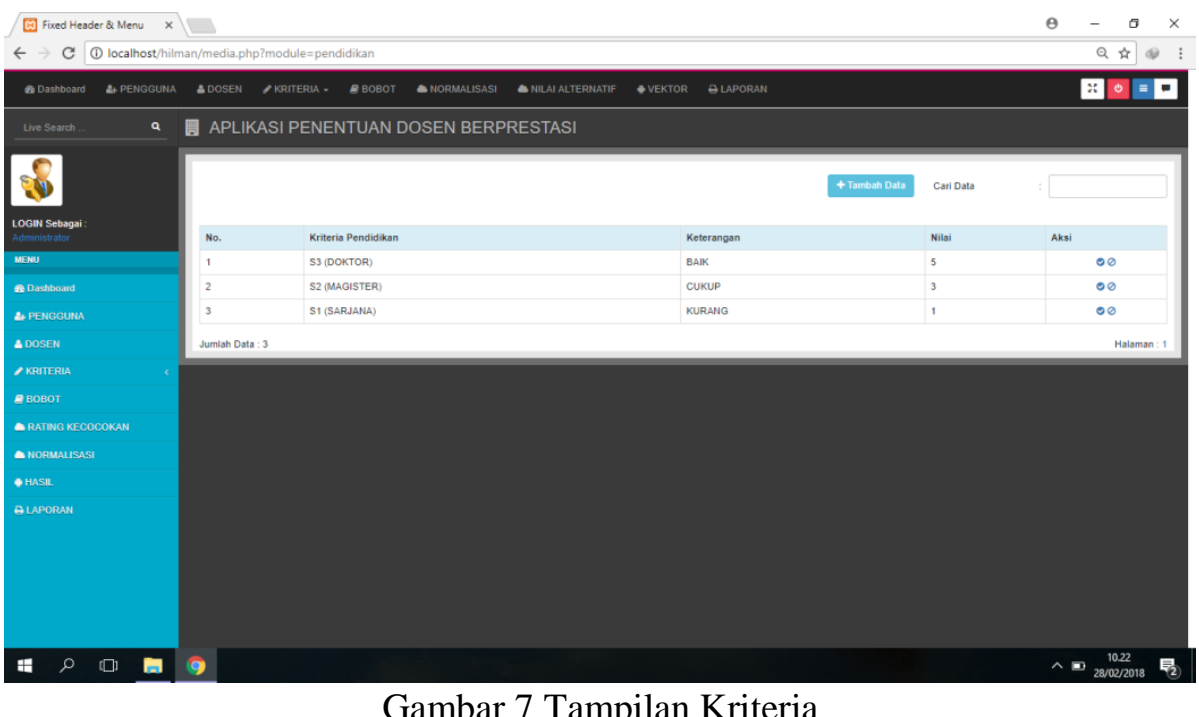

Tampilan menu bobot terdiri dari tombol tambah untuk menambahkan nilai bobot yang akan digunakan, tombol edit untuk mengedit nilai bobot dan tombol hapus untuk menghapus nilai bobot, berikut ini gambar 8 menu bobot : 


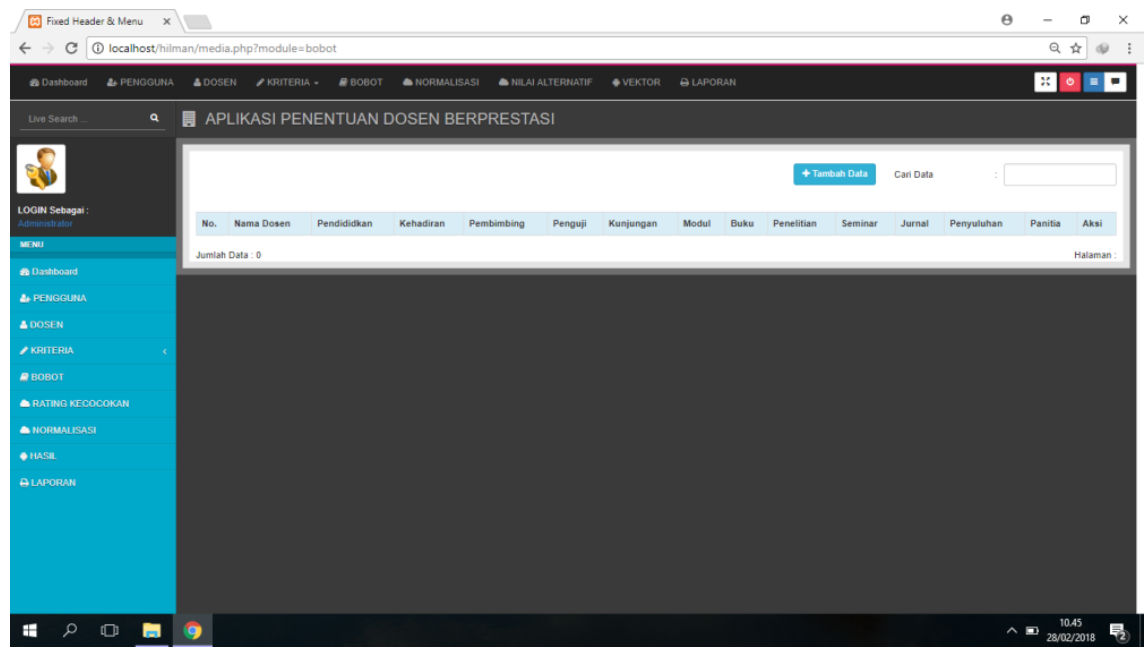

Gambar 8 Tampilan Menu Bobot

Menu normalisasi hanya menampilkan data dari perhitungan normalisasi matrix X, gambar sebagai berikut :

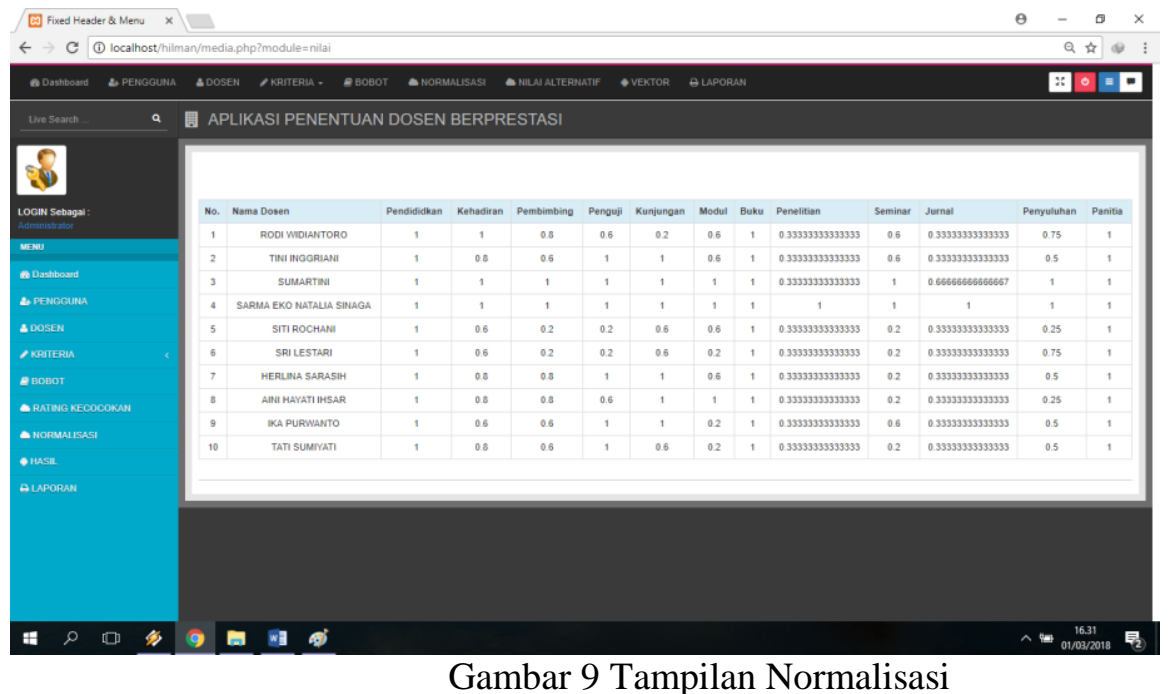

Menu hasil hanya menampilkan semua nilai dosen yang telah di input, gambar 10 sebagai berikut : 


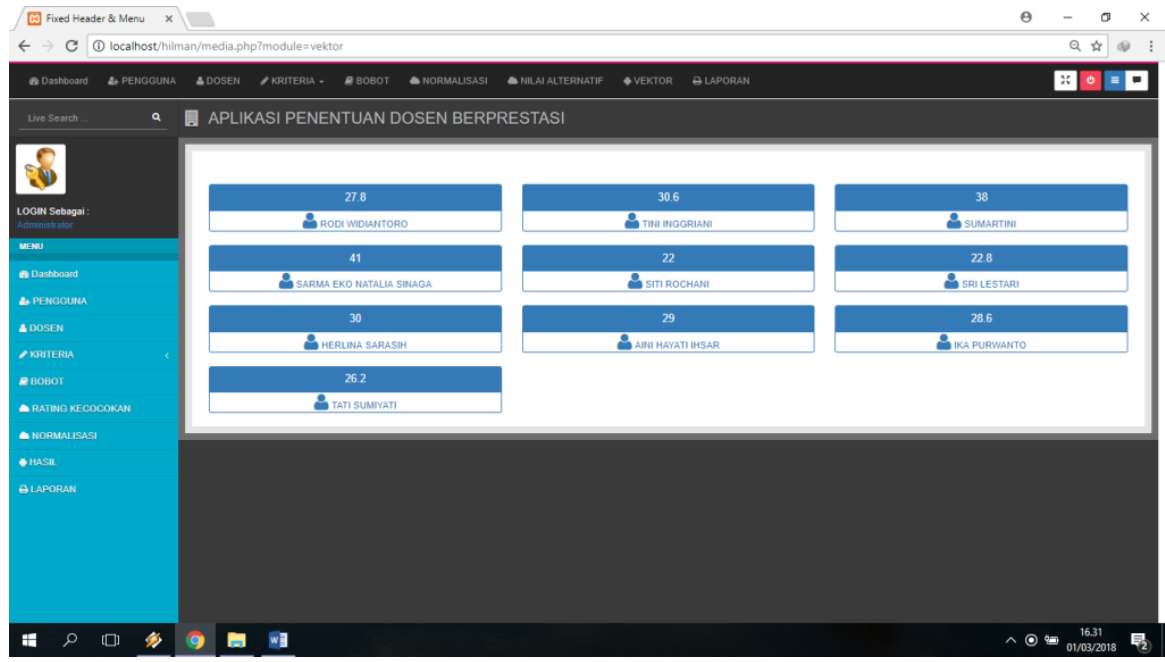

Gambar 10 Tampilan Nilai Dosen

Tampilan menu laporan hanya berisikan pencarian nama nama dosen yang akan di cetak atau diprint berdasarkan berdasarkan kebutuhan, gambarnya sebagai berikut :

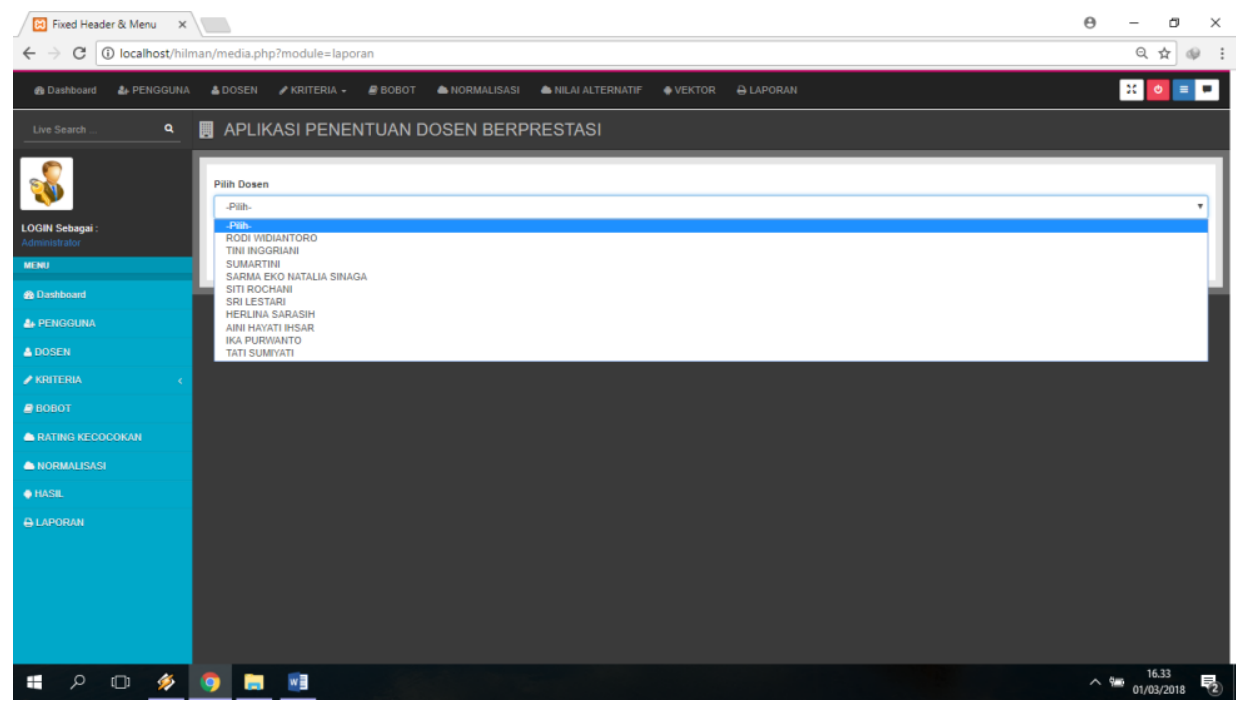

Gambar 11 Tampilan Laporan

Berikut ini menu utama user setelah login, hanya ada tampilan dasboard, Hasil dan Laporan, seperti gambar 12 berikut ini : 


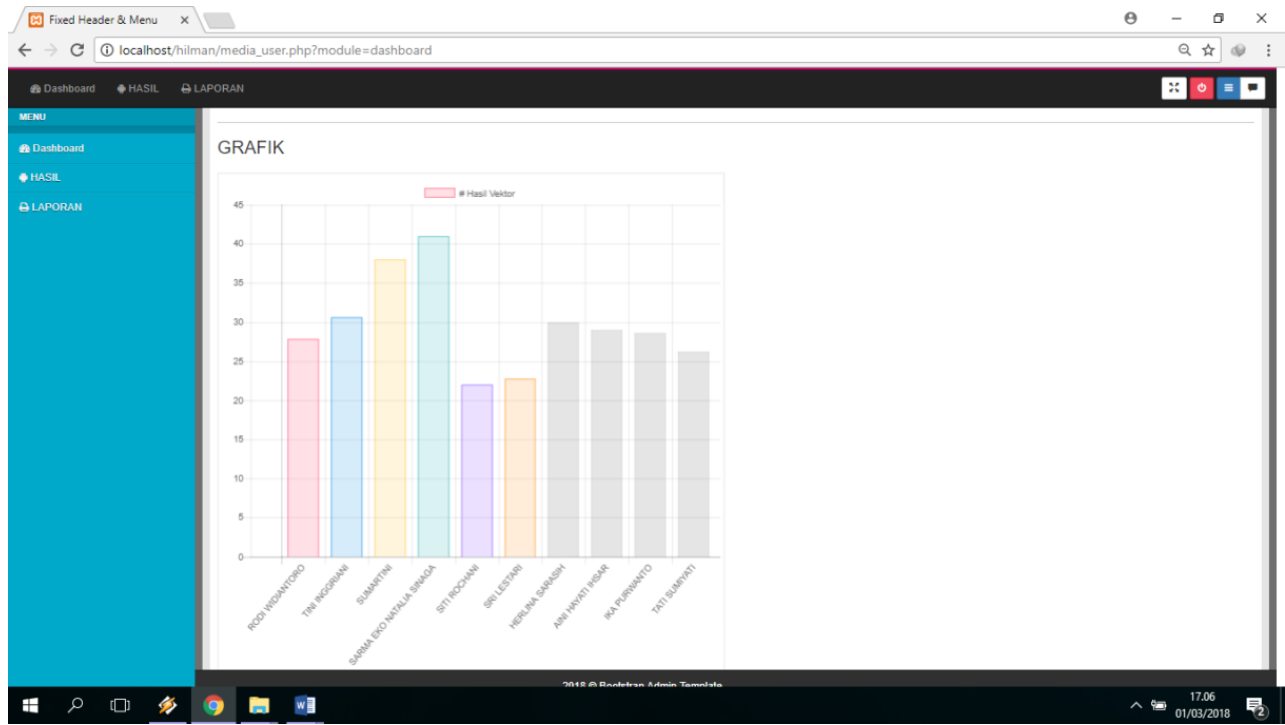

Gambar 12 Dashboard User

\section{KESIMPULAN}

Berdasarkan hasil penelitian yang telah dilakukan pada Akademi Keperawatan Yatna Yuana Lebak terhadap Rancangan Aplikasi Penentuan Dosen Berprestasi, maka dapat disimpulkan bahwa :

1. Dengan adanya sistem penentuan dosen berprestasi dapat membantu dalam pengambilan keputusan untuk menentukan Dosen Berprestasi Pada Akademi Keperawatan Yatna Yuana Lebak.

2. Rancangan sistem penentuan dosen berprestasi dapat berfungsi dengan baik ditunjukkan dengan tersedianya kecepatan informasi yang diperoleh dalam bentuk dashboard maupun laporan-laporan kriteria dosen berprestasi dalam bentuk tabel yang dapat dicetak, sehingga penyediaan kecepatan layanan informasi yang dibutuhkan dapat diperoleh secara akurat dan effisien.

\section{SARAN}

Berdasarkan pembahasan tentang implementasi sistem ini, dapat disampaikan beberapa saran untuk digunakan pada penelitian selanjutnya, antara lain :

1. Disarankan sistem yang dikembangkan dapat diimplementasikan menggunakan infrastruktur cloud-base, sehingga akses kedalam sistem jauh lebih fleksibel.

2. Sebaiknya Sistem Penentuan Dosen Berprestasi dapat dikembangkan dalam bentuk aplikasi mobile device (android/windows mobile base) agar proses akses yang dilakukan pengguna akan jauh lebih mudah.

Untuk penelitian lebih lanjut, sebaiknya melakukan pengembangan penelitian yang sejenis tetapi dengan pokok bahasan yang berbeda, supaya dapat dilihat bahwa sistem penentuan dosen berprestasi sudah sesuai untuk diterapkan

\section{DAFTAR PUSTAKA}

[1] Kursini (2007). Konsep dan Aplikasi Sistem penunjang Keputusan. Yogyakarta : Andi 
[2] Leni Natalia Zulita, Sistem pendukung keputusan menggunakan metode saw untuk penilaian dosen berprestasi (studi kasus di universitas dehasen bengkulu), (Jurnal Media Infotama, Vol.9, No.2, September 2013)

[3] Nugroho Joko Usito, Sistem pendukung keputusan penilaian proses belajar mengajar menggunakan metode simple additive weighting (saw), Program Pascasarjana Universitas Diponegoro Semarang 2013

[4] Rina Hapsari, Sistem pendukung keputusan untuk evaluasi kinerja dosen dengan metode saw di Amik Amikom Cipta Darma Surakarta,Amikom Yogyakarta 2013

[5] Zakiah Ma'ruf Safitri, Yana Adharani, Emi Susilowati, Penerapan metode simple additive weighting untuk penilaian kinerja dosen, Simposium Nasional Teknologi Terapan (SNTT)3 2015 ISSN: 2339-028X

[6]Solikhin, Rancang Bangun Sistem Pendukung Keputusan Penilaian Persepsional Dosen Menggunakan Algoritma Fuzzy Simple Additive Weighting (FSAW), Himsya-Tech Vol. 12 No.1, Januari 2016 ISSN 1907-2074

[7]Sri Eniyati dan Rina Candra Noor Santi, Perancangan Sistem Pendukung Keputusan Penilaian Prestasi Dosen Berdasarkan Penelitian dan Pengabdian Masyarakat, Jurnal Teknologi Informasi DINAMIK Volume XV, No.2, Juli 2010 : 136-142 